Prosiding Seminar Nasional Integrated Farming System, Gorontalo 25-26 November 2018

"Pembangunan Pertanian-Peternakan-Perikanan Berkelanjutan Menuju Ketahanan Pangan Nasional"

\title{
ANALISA POTENSI ECENG GONDOK (Eichhornia crassipes ) DANAU LIMBOTO SEBAGAI PAKAN TERNAK
}

\author{
Pomolango Ramlan ${ }^{1}$, Merita Ayu Indrianti ${ }^{1}$ \\ ${ }^{1}$ Fakultas Ilmu Pertanian Universitas Muhammadiyah Gorontalo sahabatonggi@gmail.com \\ ${ }^{2}$ Fakultas Ilmu Pertanian Universitas Muhammadiyah Gorontalo ayu_sutarto@yahoo.com \\ Email Untuk Korespondensi: sahabatonggi@gmail.com
}

\begin{abstract}
ABSTRAK
Pakan merupakan faktor penting yang menentukan keberhasilan usaha peternakan. Tinggi rendahnya nilai suatu bahan pakan ditentukan oleh kualitas dan kuantitas nutrien yang terkandung di dalamnya. Berbagai penelitian tentang penerapan teknologi pengolahan pakan telah dilakukan untuk mencari bahan baku pakan alternatif. Usaha tersebut untuk mengurangi impor bahan baku pakan dan menurunkan biaya produksi. Eceng gondok adalah tumbuhan air yang sering merusak lingkungan, dapat menyumbat saluran irigasi, mempercepat hilangnya air, mencemari area penangkapan ikan dan penyebab degradasi lingkungan habitatnya terutama di danau,sungai dan rawa. Enceng gondok tumbuh dengan cepat, sehingga diperlukan upaya untuk menanganinya agar tidak mengganggu dan merusak lingkungan. Penelitian ini bertujuan menganalisa potensi dari tanaman Eceng gondok (Eichornia crasipes) Danau Limboto Kabupaten Gorontalo sebagai pakan ternak. Sebanyak $15 \mathrm{~kg}$ daun dan batang eceng gondok segar diambil dari Danau Limboto dan dianalisa kandungan nutrisinya. Hasil penelitian menunjukkan kandungan nutrisi eceng gondok adalah : Bahan Kering (BK) 17.20 \%, Serat Kasar (SK) $4.08 \%$, Protein Kasar (PK) $3.55 \%$, Karbohidrat $8.22 \%$ dan Kadar Abu sebesar $3.93 \%$. Sebagai tanaman yang berpotensi pakan ternak, eceng gondok dapat diberikan dalam bentuk segar, kering dalam bentuk tepung maupun diolah dalam bentuk silase dan melalui proses fermentasi .
\end{abstract}

Keyword: Eceng Gondok, Nutrisi, Analisa Proksimat, Danau Limboto

\section{PENDAHULUAN}

Pakan merupakan salah satu faktor penting yang akan menentukan keberhasilan usaha peternakan. Tinggi rendahnya nilai suatu bahan pakan ditentukan oleh kualitas dan kuantitas nutrien yang terkandung di dalamnya. Bahan pakan merupakan kebutuhan pokok bagi setiap ternak. Sebagian besar bahan pakan terdiri dari unsur - unsur pokok yaitu air, mineral, karbohidrat, lemak dan protein. Kelima unsur ini dibutuhkan oleh hewan ternak dan manusia untuk pertumbuhan, produksi, reproduksi dan hidup pokok. Makanan ternak berisi zat nutrisi dengan kandungan yang berbeda-beda karena itu perlu dilakukan.

Eceng gondok adalah tumbuhan air yang sering merusak lingkungan danau dan sungai, dapatmenyumbat saluran irigasi, mempercepat hilangnya air, mencemari area penangkapan ikan. Eceng gondok tumbuh dengan cepat, sehingga diperlukan upaya untuk menanganinya agar tidak mengganggu dan merusak lingkungan. Pemanfaatan enceng gondok sebagai tanaman pakan belum banyak digunakan, sedangkan pertumbuhan dan ketersediaannya sangat memadai pada musim kemarau maupun musim hujan. Eceng gondok memiliki kadar air yang tinggi dan serat kasar berupa hemiselulose, keduanya sangat membatasi dan menghambat pemberian pada ternak. Kelemahan tersebut dapat mengganggu palatabilitas dan kecernaannya, sehingga dalam pemanfaatannya harus diolah terlebih dahulu contohnya dalam bentuk fermentasi. Menurut Bidura et al.(2005) fermentasi oleh mikrobia mampu mengubah makromolekul komplek menjadi molekul sederhana yang mudah dicerna oleh unggas dan tidak menghasilkan senyawa kimia beracun.

Eceng gondok di Danau Limboto tumbuh meluas dengan sebaran mencapai sekitar $30 \%$ dari luasan danau. Eceng gondok akan bergerak dari Barat-Utara ke Timur dan Selatan. Pergeseran tersebut sejalan dengan perubahan musim khususnya arah mata angin dimana eceng gondok akan terdeposisi di bagian selatan danau. Persebaran tanaman gulma air tersebut terdapat di bagian Barat, Tengah, Tenggara dan Utara danau Limboto.Konsentrasi terbesar ada di bagian tengah danau dan bergerak sesuai musim. Tanaman ini bergerak dari arah Barat dan Utara ke bagian Timur dan Selatan.

Laju pendangkalan danau akibat erosi dari sungai-sungai yang bermuara di danau ini sangat besar. Pada tahun 1932, rata-rata kedalaman Danau Limboto 30 meter dengan luas 7.000 Ha. Pada tahun 1955 kedalaman danau menurun menjadi 16 meter. Dan dalam tempo 30 tahun, (tahun 1961) rata-rata kedalaman Danau Limboto telah berkurang menjadi 10 meter dan luasnya menyusut menjadi 4.250 Ha. Pada tahun 1990 - 2008 kedalaman Danau Limboto tinggal rata-rata 2,5 meter dan luasnya yang tersisa tinggal $3.000 \mathrm{Ha}$. Pendangkalan danau dan kerusakan hutan menyebabkan terjadinya banjir. Setiap tahun terjadi pendangkalan danau setinggi $46.66 \mathrm{~cm}$ dan penyempitan danausebesar 
66.66 hektar dan terjadi penurunan muka air normal danau sebesar kurang lebih $1,75 \mathrm{~cm}$. Penurunan daya tampung danau, menyebabkan terjadi banjir. Dalam kurun waktu 52 tahun Danau Limboto berkurang 4304 ha $(62.60 \%)$. Jika kita hitung per tahunnya, tingkat penyusutan danau mencapai 65.89 hektar. Diperkirakan pada tahun 2025, Danau Limboto lenyap dari muka bumi Gorontalo.

Eceng gondok (Eichhornia crassipes) dalam perkembangannya sebenarnya merupakan tanaman yang bermanfaat dan berpotensi sebagai pakan alternatif. Bagian dari tananaman seperti daun dapat dimanfaatkan sebagai bahan pakan ternak/ikan, Eceng gondok juga dapat dimanfaatkan baik sebagian atau total untuk pembuatan kompos maupun mulsa. Perlakuan yang diberikan pada eceng gondok diharapkan mampu meningkatkan nilai ekonomis dan dapat menekan biaya pakan. Salah satu alternatifnya adalah dimanfaatkan sebagai bahan pakan ternak (Mangisah et al.,2009). Pemanfaatan eceng gondok sebagai tanaman pakan belum banyak digunakan (inkonvensional) oleh masyarakat, sedangkan pertumbuhan dan ketersediaannya sangat memadai pada musim kemarau maupun musim hujan. Pemanfaatan eceng gondok dengan penerapan bioteknologi akan meningkatkan kandungan nutrisi dan daya cerna eceng gondok.

Salah satu alternatifnya adalah dimanfaatkan sebagai bahan pakan ternak. Namun pemanfaatan eceng gondok sebagai pakan mempunyai beberapa kelemahan, antara lain : kadar airnya tinggi, teksturnya halus, banyak mengandung hemiselulosa dan proteinnya sulit dicerna. Oleh karena itu perlu dilakukan pengolahan terlebih dulu baik pengolahan fisik, kimia, biologi maupun kombinasinya. Pengolahan eceng gondok sebagai pakan dengan cara dibuat tepung kemudiandifermentasi. Salah satu cara pengolahan secara biologi adalah fermentasi dengan media mikroba atau menggunakan Aspergillus niger atau EM-4 yang umum beredar di pasaran.

Analisis proksimat merupakan metode yang tidak menguraikan kandungan nutrien secara rinci, namun berupa nilai perkiraan (Soejono, 1990). Metode ini dikembangkan oleh Henneberg dan Stockman dari Weende Experiment Station di Jerman pada tahun 1865 (Tillman et al., 1991). Analisis proksimat berupa analisa kadar air, kadar abu, bahan kering, analisa protein kasar, lemak kasar dan analisa serat kasar. Pada setiap analisis terdapat metode-metode yang berbeda. Analisis proksimat bermanfaat dalam mengidentifikasi kandungan zat makanan dari suatu bahan pakan atau pangan yang belum diketahui sebelumnya yang selanjutnya disebut sampel. Selain dari itu, analisis prokimat merupakan dasar dari analisis-analisis yang lebih lanjut.

Berdasarkan uraian tersebut diatas maka penelitian ini dilakukan dengan tujuan untuk mengetahui potensi dan kandungan nutrisi eceng gondok (Eichhornia crassipes) Danau Limboto sebagai alternatif pakan ternak

\section{METODOLOGI}

Penelitian ini dilaksanakan mulai bulan Mei sampai dengan bulan Juni 2018 dengan lokasi penelitian di Laboratorium Lapangan Fakultas Ilmu-Ilmu Pertanian Universitas Muhammadiyah Gorontalo, Pentadio Timur Kabupaten Gorontalo. Untuk analisa kandungan nutrisi eceng gondok dilakukan di Balai Riset dan Standarisasi Perindustrian Manado. Fermentasi Eceng gondok untuk meningkatkan palatabilitas dan kecernaan dilakukan di Laoratorium Lapangan Faperta Universitas Muhammadiyah Gorontalo.

Bahan dan Alat yang digunakan dalam penelitian ini terdiri dari daun dan batang eceng gondok, bahan untuk fermentasi, wadah untuk penampungan, ember, karung, peralatan pemotongan, choper, parang, peralatan untuk penjemuran, wadah untuk proses fermentasi.

Pengolahan eceng gondok terfermentasi meliputi: eceng gondok dipotong, untuk penyeragaman umur dan batang dan daun dipanen yang berumur 30 hari. Daun dan batang dipotong dan dikeringkan dengan sinar matahari. Potongan enceng gondok kering dimasukkan ke dalam plastik dengan ketebalan $10 \mathrm{~cm}$, kemudian campuran mikroba berupa cairan EM4 ditaburkan di atasnya. Potongan eceng gondok ditumpuk di atas tumpukan sebelumnya, EM4 ditabur kembali dan seterusnya sampai plastik terisi penuh, kemudian ditutup rapat.

\section{HASIL DAN PEMBAHASAN}

Berdasarkan hasil analisis proksimat yang dilakukan pada daun dan batang eceng gondok yang ada di Danau Limboto, maka kandungan nutrisinya dapat dikatakan berpotensi sebagai bahan pakan ternak alternatif dengan kandungan Bahan Kering (BK) sebesar $17.20 \%$. Sedangkan kandungan Protein Kasar sebesar 3.55 \%, Serat Kasar (SK) 4.08 \%, Karbohidrat 8.22 \%, Lemak $1.50 \%$ 
Prosiding Seminar Nasional Integrated Farming System, Gorontalo 25-26 November 2018 "Pembangunan Pertanian-Peternakan-Perikanan Berkelanjutan Menuju Ketahanan Pangan Nasional"

dan Kadar Abu 3.93 \%. Analisa ini menggunakan Metode Analisa Proksimat SNI 01-2891-1992 Butir 5.1-6.1-8.1 dan 11. Sedangkan untuk kandungan Protein Kasar (PK) menggunakan metode SNI 01-2986-1992 dan Karbohidrat dengan metode perhitungan.

\section{KESIMPULAN}

Berdasarkan hasil analisis proksimat yang dilakukan pada daun dan batang eceng gondok yang ada di Danau Limboto, maka kandungan nutrisinya dapat dikatakan berpotensi sebagai bahan pakan ternak Pembuatan tepung dari bahan daun dan batang eceng gondok menunjukkan perubahan warna menjadi kecoklatan. Hasil fermentasi eceng gondok menunjukkan perubahan pada warna yang menjadi kecoklatan dan bau harum yang khas fermentasi. Perubahan ini merupakan salah satu indikator naiknya palatabilitas ternak terhadap bahan pakan ini.

\section{UCAPAN TERIMA KASIH}

Ucapan terima kasih kami sampaikan kepada mahasiswa program Studi Peternakan 20142015 yang telah membantu dalam pengambilan sampel penelitian ini. Pimpinan Fakultas Ilmu Ilmu Pertanian Universitas Muhammadiyah Gorontalo yang telah meminjamkan Laboratorium Lapangan Faperta untuk tempat penelitian.

\section{REFERENSI}

AOAC. 1990. Official Methods of Analisis. Asosiation of Official Analitic Chemist,Washington DC. USA.

Given, D. I., I. Owen., R. F. E. Axford., H. M. Omed. Forage Evaluation in Ruminant Nutrition. Wollingford: CABI Publishing : 281-300.

Hafes. E. S. E. 2000. Metode Analisis Proksimat. Jakarta: Erlangga.

Haris, L.E. 1970. Nutrition Research Technique for Domestic and Wild Animal Vol.1Utah State University. Logan. Utah.

Karra, 2003. Ilmu Makanan Ternak Dasar. Gajah Mada University. Yogyakarta.

Khairul. 2009 . Ilmu Gizi dan Makanan Ternak. Penerbit Angkasa. Bandung.

Krishna G and S.K. Ranjhan. 1980. Laboratory Manual for Nutrition Research Vikas publising house PVT Ltd. Sahibabad. India.

NRC. 2001. Nutrient Requirements of Beef Cattle: Seventh Revised Edition: Update 2000. Subcommittee on Beef Cattle Nutrition. Committee on Animal Nutrition. National Research Council.

Tillman, A.D., et al. 2005. Ilmu Makanan Ternak Dasar. Gadjah Mada University Press. Yogyakarta. Winarno., 1997. Kimia Pangan dan Gizi, PT. Gramedia Pustaka Utama, Jakarta. 